\title{
Making National Debts National Blessings
}

\author{
By Simon N. Patten, Ph.D. \\ Philadelphia, Pa.
}

J AY COOKE, the noted financier of our Civil War, invented the maxim: "National debts are national blessings." This seems a paradox and yet its truth can readily be verified. The thought is not that destruction is the motive for industry but rather that necessity is the mother of invention. Men and institutions are too conservative. Controlled by habit, tradition and routine they lag behind the actualities which evolution creates. The world moves on by huge mutations and not by a multitude of minute variations. There is thus both theory and fact back of Jay Cooke's slogan even if war slackers will not admit its validity. The world today faces such mutation, the destructive part of which is already apparent. War debts are its visible evidence. The reconstructions are ahead. World debts are the force which will make us accept the new order.

This world debt may be met in two ways. If we let blind forces decide who shall bear the loss, a great financial panic will occur. World values will fall to a far greater extent than the loss actually incurred and he will bear the burden whose values relative to others fall the most. The nominal bearers of burdens are thus not their ultimate bearers. The French did not pay the indemnity of the war of 1870 . The bills were settled by the financial panic of 1873 through which America lost more than France because her values were more inflated and hence less stable. Fix the payment of the present war debt as treaties may, England and America will bear the burden of it if a financial panic determines on whom the payment shall rest. From him that hath shall be taken, is the crude law of panics and who is he who hath, but America? Our war debt and the inflation of money and credit which goes with it amounted to thirty billion dollars. The depression due to a world panic would cost us a like sum. Together our losses would be a quarter of the two hundred billion of values we had when the war began.

So much for one way of meeting a world crisis by paying for the 
war by our blood, sweat and suffering and then paying for it again by the disasters which follow in its trail. The other method converts disaster into a blessing by making industrial readjustments pay national debts and in addition create a surplus to enable other long needed reforms to be made. If the new situation stirs our energies, removes prejudices, overcomes conservative stupidity, forces the use of new industrial mechanisms and so modifies our political institutions that they can function in our modern world, -if all these and other available adjustments are made, our children will bless the war instead of regarding it as a curse.

It was the debt of the Revolutionary War that forced the adoption of the national constitution, which constitution, through its benefits, paid for the war without taking a dollar from the pockets of anyone. Again in our Civil War did Jay Cooke's maxim prove its worth. Its debt was paid not by the sweat of labor but by the great inventions of the epoch. The Western expansion, the harvester and the sewing machine and the locomotive, besides paying the national debt, left a surplus for all to enjoy. Shall we face debt as our fathers did by corresponding improvements or shall we cause disaster by stupid inaction? Below is a plan which, protecting industry from loss, would yield a gain for all to enjoy.

\section{Explanations}

In the plan there is little new. It contains merely a clear statement of the cogent demands of the leading agents in production in language which can be understood and accepted by other agents and by the public. The new is not in these demands but in the way they are to be met. In the past, each group has presented its claims and assumed that their increase of income should come at the expense of other agents. In contrast to this I would find what are the legitimate demands of each agent and then see if these added costs cannot be met, not at the expense of others, but by an increase of industrial efficiency. I make therefore a national budget of increased costs and one of possible improvements to see if the costs of the one cannot be paid out of the surplus of the other. If so each group has an interest in an enlarged production which would liquidate its claims without creating burdens for others to bear. The data I use in this 
compilation are those of 1914 unless they are plainly abnormal. All changes and per cents are differentiations from this base.

The urgent demands of the workers are for shorter hours, increased pay, the right to organize, and compensation for risk and disability. The farmers want higher prices for their products but resist the increased prices which the demands of other agents would make. The laborers want more wages at the expense of capital, and employers desire more profits through reduced labor costs. Each group thus assumes a fixed national income but demands an increase of its share at somebody's else expense. The struggle is thus transferred to the area of distribution with all the bitterness which such struggles make.

The national wage bill for 1914 was ten billion dollars. The total national income at that time was perhaps forty billions, wages receiving on the average about a quarter of the value of the goods produced. Another estimate reaches the same result. The population of the nation was one hundred millions. Ten billions in wages would mean one hundred dollars for each man, woman and child. As the typical family is composed of parents, three children and one dependent, this would give $\$ 600$ as the average income of workmen's families, a sum verified by other available data. If these be the facts, a 50 per cent rise in wages would demand the payment of five billion dollars annually. Much would be returned in increased efficiency but not enough to meet this bill. A fair estimate would be that the deficit created would be about 40 per cent of the whole, or two billion dollars. To pay this, together with the assumption by the employers of industrial liabilities, would involve an increase of 15 per cent in the value of products above those of 1914 . This would be the cost of providing a decent standard of life for workers other than those general changes demanded by the good of the whole nation.

The need of the farmer is primarily for a stability of agricultural prices. At present, farming is a gamble and the mental attitude of the farmer is one of extreme pessimism. This seriously reduces his effectiveness and prevents the increase of agricultural products to the degree demanded by public welfare. A second need is for protection against race degeneration in rural communities and a third is for enforced coöperative enterprises which will enable joint production to be carried on to an advantage. The isolated 
self-sufficing farmer, however valuable in the past, is now a drag on every rural community. Coöperative farming is as necessary as large scale production in industry and would produce as valuable results.

To gain a stability for agricultural prices demands not a fixing of average price but of a point below which prices cannot fall. At this point goods must be taken off the market, stored or transformed into products capable of increased transportation, or freed from the danger of deterioration. This will be the public cost of stable farming but it will be more than met by the lower average price. I have excluded corn and oats from the action of this measure because their prices are sufficiently stable under present conditions. The price of land fitted for their production is also above the $\$ 100$ limit. The need of price fixing is especially apparent in the case of wheat and potatoes. All garden products would be likewise benefited. Germany has found a minimum price of potatoes extremely helpful.

The productivity of land increases as its price rises until the point of maximum productivity. I have assumed this point to be reached when land is valued at $\$ 100$ per acre. Higher land prices tend to emphasize net at the expense of gross product and to increase the evils of tenant farming. This evil should be met by taxing rented land.

I also suggest a zone tariff for transportation in the place of the mileage rate now enforced. Mileage rates make the cost to the consumer that of the most disadvantaged farm while the benefits of lower rates for nearer points do not go to the farmer but are absorbed in increased land values. A zone rate the same for all producers would thus lower consumers' costs, cause products to be produced at points of greatest advantage, and give stability to all producers.

With the solutions suggested for the improvement of the worker and the farmer the public is familiar and on the whole favorably disposed. If it can be shown that they are practical they would be eagerly adopted. But the changes involved in an efficient business program would meet with severe opposition. The doctrine of free competition has been thoroughly instilled into the public mind by ages of practice; the transformation to an epoch of industrial restriction will therefore not be an easy task. The fear 
of monopoly is a menace which can be avoided only by a rigid system of state regulation. The experiments of the war epoch have, however, shown how this can be done and their success constitutes one of the great benefits of the war.

The assumed inability to fix reasonable prices either for goods or services has not proved so great as was assumed. Bookkeeping has become a science and cost accounts should be kept by every large establishment. When some common system of accounting has been devised and enforced, sound estimates can be made as to each element of cost and of the relation of cost to profit. Reasonable prices and fair profits are then an easy task to determine. Sometime the transition from competition to regulation must be made. Why not make it now when its effects are so much needed to solve other problems? It is through the increase of industrial efficiency that the costs of progress must be met. Distributive schemes fail through the animosities they create. Increased production and mutual aid are the only solvents of the problems inherited from long ages of want, and made vivid by the antagonisms of race and class.

Government regulations of this sort leave the individual as he is with all the variety of motive and interest which men now exhibit. The scope of individual initiative and personal choice would be largely increased and made real to all classes. Were all the proposed improvements made, no one would note thechange on the street except for the absence of poverty and the presence of cheer. The difference would show itself in the mechanism of industry and the coördination of effort. When men work they would work with each other and not at cross purposes. Industrial units would be on so large a scale that the individual would be no more conscious of them than that the world turns on its axis. It is bad, imperfect mechanisms so small and complicated as to demand individual attention which make us their slaves. Great mechanisms are the basis of personal freedom. They save time and energy for objects of greater personal moment. Friction can thus be removed and self-initiative encouraged without the repression which a close supervision of individual acts creates. It is the individual who should be free, not the great mechanisms of production. 


\section{Conclusion}

The cost of the war may amount to thirty billion dollars to which a like sum may be added if a lack of foresight permits a world crisis to generate its destructive power. A full coöperation between worker, farmer and producer is needed to thwart this evil and to create the fund out of which the deficits of progress may be met. Mutual effort and the utilization of known devices would add from sixteen to twenty billions to the annual income of the nation. The cost of this would not be more than eight billions and might be much less. This would mean a 50 per cent increase in wages, a 5 per cent return on safe investment, $\$ 100$ an acre as the average price of farming land, stable prices for all agricultural products, a $\mathbf{1 0}$ per cent return on active capital, a sixty billion annual income and an increase of national wealth from two hundred to three hundred billion dollars. Such is the change measured in dollars. The improvement in heath, longevity, education and efficiency are equally apparent. A world is in sight in which none are ignorant, few die before the age of sixty, where poverty is unknown and disease ceases to terrify. Shall we let old antagonisms and senseless stupidity keep us from a goal which mutual good will could readily attain?

\section{National Budget}

New sources of national income

Control of mineral products. . . . $\ldots \ldots \ldots \ldots \ldots \ldots \ldots, \quad \$ \ldots 00$

Increased use of tropical products. . . . . . . . . . . . . $\quad 500$

The ultilization of chemistry $\ldots \ldots \ldots \ldots \ldots \ldots \ldots \ldots \ldots, \quad 500$

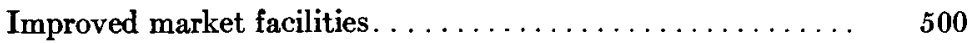

Railroad economies. . . . . . . . . . . . . . . . . $\quad 500$

Decrease in adverse balance of trade.............. 500

Water rights and water ways $\ldots \ldots \ldots \ldots \ldots \ldots \ldots \ldots \ldots .500$

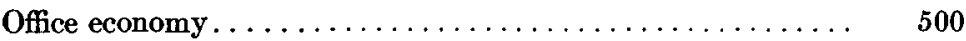

Administrative efficiency $\ldots \ldots \ldots \ldots \ldots \ldots \ldots \ldots \ldots \ldots, \mathbf{1 , 0 0 0}$

Food conservation. . . . . . . . . . . . . . . . . . . 1,000

Prevention of disease . . . . . . . .

The standardization of products $\ldots \ldots \ldots \ldots \ldots \ldots \ldots \ldots, \quad 2,000$

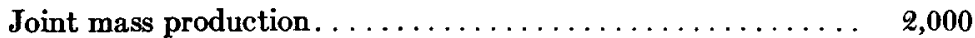

Stabilization of agricultural prices . . . . . . . . . . . .

Elimination of sales costs. . . . . . . . . . . . . $\ldots \ldots \ldots, \ldots \ldots$

Increased efficiency of labor $\ldots \ldots \ldots \ldots \ldots \ldots \ldots \ldots \ldots \ldots \quad \mathbf{3 , 0 0 0}$

Total ............................. \$16,000 
Additional National Costs

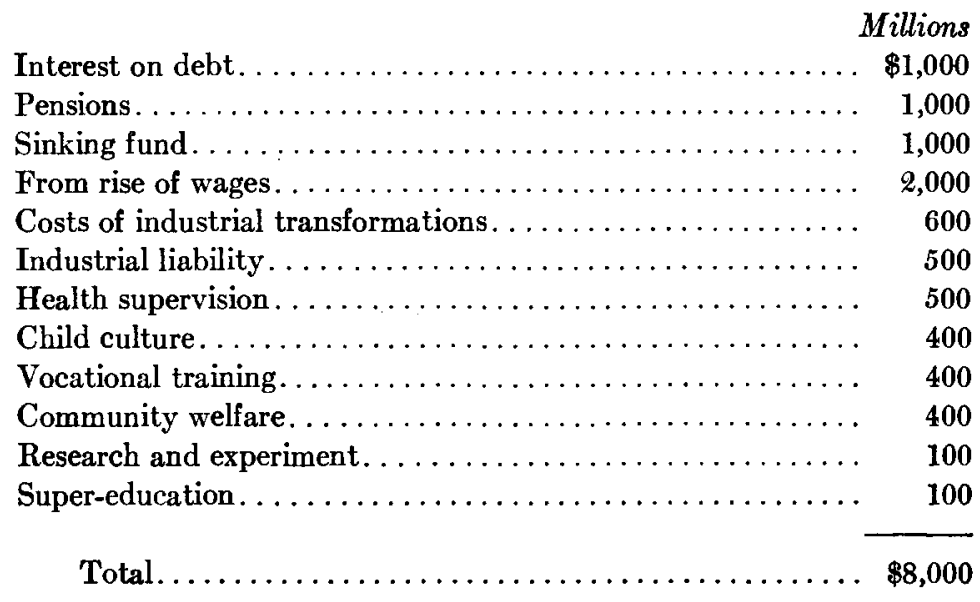

\section{Farm Maxims}

1. The increase of production comes not from an enlarged acreage but from a better use of good land. A bad year for good farmers is a good year for bad farmers.

2. Any product which can be raised south of the frost line should be raised there.

3. Gross production is limited when the price of land rises above $\$ 100$ an acre.

4. The farming unit should not be less than that needed to employ two men at full time.

5. The dearer stock and tools are in the end the cheaper.

6. The home uses of food are more important than those of the market.

7. Farm prices should not be a gamble but a certainty. Stable prices are better than alternating high and low prices.

8. Local associations should control the occupancy of farms and enforce coöperative enterprise.

9. Every community needs defensive measures to protect it from race degeneration, and coercive measures to promote production.

10. Each agricultural unit whose industry conforms to public interest should be placed in a position to compete on the common market. For this end a zone tariff affords the best solution.

11. All staple food crops except corn and oats shall have a 
guaranteed minimum price estimated at 80 per cent of the average price for the past ten years.

12. No importation of farm products shall be permitted where the price falls below the average of the past ten years.

13. Experiments of national import shall be made in the preservation of food products from season to season and when successful shall be operated on a sufficient scale to stabilize food prices.

14. Elevators, stock yards and other means of marketing products shall be made common property subject only to such fees as are needed for their maintenance.

15. Farm tools and improvements shall be exempted from taxation except for schools and roads. Nor shall dairy farms be taxed for more than 60 per cent of their value.

16. All rented land other than to members of the same family shall be subject to a tax of 10 per cent on the rent received.

\section{Labor Maxims}

1. The working day shall be limited to eight hours, the week to forty-four hours and each year shall contain a two weeks' holiday with full pay.

2. The expense of removing the causes injuring laborers or reducing their vitality shall be regarded as legitimate costs to be borne by each industry.

3. All attained standards shall be regarded inviolate.

4. Laborers shall favor industrial improvements and share in their advantages equally with employers.

5. When labor is displaced by improvements, this labor shall be compensated for its loss out of the profit arising from the improvement. When this cannot be measured, the burden shall be accepted by the state and paid for out of the general surplus of society.

6. All health regulations affecting the workers shall be regarded as public charges if their causes lie beyond the control of specific industries.

7. Where the work of an industry incapacitates or reduces the efficiency of the worker before sixty, his support is a legitimate charge on this industry until that age is reached.

8. One thousand dollars shall be regarded as the minimum standard necessary to provide for the support of a family. Where 
superior efficiency is demanded in any occupation, sufficient additional remuneration shall be given to evoke the needed skill.

9. Workers shall not demand the control of the industries in which they work but they must have the right of collective action and of collective decision. They are entitled to all the facts which bear on wages, costs, prices and on industrial effectiveness. When these facts are given, no publicity shall follow unless the management and the workers fail to agree as to the policies involved.

10. Workers shall control the conditions of membership in their unions, but these regulations shall conform to public interest and be subject to public revision.

11. The education of children shall continue until the completion of their eighteenth year before which age they shall be excluded from industry except as part-time apprentices subject to the rules of the union concerned and of the educational authorities.

12. Every industry shall supply continuation schools in which the worker may attain the maximum efficiency of his occupation.

13. Where women and men do the same work their pay shall be the same. If women are excluded from unsuitable occupations, corresponding occupations shall be reserved for them subject to such regulations as their health and public welfare demand.

14. All industrial occupations shall be conducted on the ground floor and each plant so isolated that the worker may have a home of his own. Industrial plants shall be at the perimeter and not in the center of each town. The zoning of cities for this end shall be enforced by public regulation.

15. No taxes shall be laid on the food of workers nor shall special taxes be placed on their clothing or on housing material.

16. Organized labor favors coöperation with associations striving to promote public welfare and stands ready to do their part to make this larger unification effective.

\section{Business Maxims}

1. Joint mass production shall be encouraged under such regulations as conserve public interest. To this end a national board of industrial control shall be formed with powers similar to the interstate commerce commission.

2. National boards shall also be constituted to control water privileges, forests, mineral resources, the standardization of products and the protection of investments. 
3. The legitimate capitalization of these joint enterprises shall be their present physical valuation plus 20 per cent.

4. If the present capitalization exceeds this limit, one-half of the net profits shall be set aside to reduce liabilities or to increase the value of plants.

5. The return on capital thus invested shall be double that of secure investments. Any excess of this return shall be divided equally between the enterprise and the public.

6. On the boards for the control of joint enterprises both the workers and the public shall have representation.

7. In these joint enterprises injury to workers or a reduction in their efficiency shall be accepted as a burden to be met by an increased price of the goods produced. They shall not interfere with the organization of their employes nor refuse to treat with them in their collective capacity.

8. All new issues of stocks or bonds, all new corporations soliciting subscriptions, all public presentation of schemes of investment, and all attempts artificially to raise or lower prices, shall be under the national control.

9. No increase of prices shall be permitted without national consent.

10. Where the sale or purchase of commodities involves foreign commerce, joint boards of control may be established to expedite such transactions with the right to hold property, to own ships and to control business facilities in the regions where they trade. Such enterprises shall be allowed a double profit on all capital legitimately employed.

11. The unification of existing railroad systems shall be permitted when such combinations permit a better routing of goods or prevent a duplication of facilities. All gains from agreements to lower costs shall be used for betterments or to reduce liabilities. The resulting values shall not be made the basis of stock issues nor of stock dividends.

12. Where corporations have developed with complex underlying obligations a simplification shall be permitted into two classes, mortgage and stockholders. Underlying securities whose holders refuse to be partners in such simplification shall be taxed 50 per cent on the excess of their return above 4 per cent on the original cash investment. 
13. Mineral products are declared to be mutual national possessions and subject to such restrictions as to extraction and sale as public interest demands. All royalties exceeding 10 per cent of the value of the product shall be taxed 80 per cent.

14. A board for the control of agricultural products shall be formed with power to regulate price and to stabilize production.

15. Retailers shall be permitted to enact protective regulations subject to the supervision of the national board of industrial control.

16. Joint experiments for the reduction of costs shall be encouraged in all fields of production. On capital thus employed, 100 per cent profit is permitted during the first twenty years of the use of product.

\section{Postscript}

The program outlined above would suffice to meet our internal problems yet the same difficulties are encountered on a much larger scale in our international relations. Many nations are likely to be unable to meet their obligations. Even France is not free from the danger of bankruptcy. We may therefore be compelled to enter into foreign alliances to stem a world tide of disaster even if our home affairs are satisfactorily cared for.

Three policies are open to us. An international league of peace, an alliance with England and a policy of isolation. A league of peace has moral and political advantages but its influence on the economic situation would be limited. We can successfully continue a policy of isolation only by the addition to our territory of lands to the south. We have scarcely any land free from frost while tropical products are of increasing importance. With this modification, a policy of isolation could be economically successful. We are not yet dependent on world commerce for the needed industrial expansion.

There would however be many gains from an economic alliance with England to safeguard our world interests and to give our ideals and traditions a lasting supremacy. The control of the sea is now Anglo-American. If it were used for humanitarian ends not only could economic prosperity be given the whole world but much could be done to ensure political stability.

The key to world peace is in the control of the sea. Those who 
control it also shape world ideals and make world traditions. Economic prosperity is thus the forerunner of world unity and this prosperity is now in Anglo-American hands.

It seems advisable therefore to complement internal economic solutions with that larger world solution for which the position and importance of our race have made us responsible. The maxims which follow would give an external security as great as that to be obtained by the internal policy above outlined.

\section{Anglo-American Maxims}

1. The English and American people are declared to be an inseparable coterminal unit with mutual rights and duties.

2. Our inherited institutions, ideals and traditions are declared to be the only basis of a new world order. No nation shall be treated as an equal which does not accept them in their entirety.

3. No binding treaty shall be made with other nations except by the knowledge and consent of both nations. Any existing treaty violating this provision shall be revoked.

4. The assent of the Irish race is indispensable to this unity. Their rights and sentiments shall receive equal consideration to that of other integral parts of the alliance.

5. America shall have a super-sovereignty over the American continent. America and Australia shall have a like sovereignty over the Pacific ocean and its islands.

6. No nation shall have the freedom of the sea for its products which subjects its exports to any excise tax unless the proceeds are used solely for health, sanitation or industrial improvement.

7. No nation shall be given the freedom of the seas for its products which oppresses any part of its subjects on account of religion, race or other prejudices. Nor shall they keep armies beyond the need of internal protection.

8. All the mineral resources of the world shall be subject to sea control if their shipment is necessary. Nor shall tropical advantages or tropical people be exploited by any one for selfish ends.

9. The control of every sea is essential to these ends. All acquired rights shall be maintained and every precaution taken to make this control effectual.

10. This control shall not be used for the material advantage of any part of the Anglo-American realm. Nor shall it be used 
to collect debts in foreign countries nor to enforce laws. Subject to necessary restrictions the trade and commerce of the world shall be open to all on equal terms.

11. Adjunct states may be formed by either nation within its sphere of influence. Such states shall control their local affairs subject to such regulations and limitations as are needed to preserve the alliance and to extend its influence.

12. A special supervision may be exercised over states organizing themselves on an Anglo-American basis. For this end Asia Minor, Persia and China are declared to be under Anglo-American protection.

13. No interference in the affairs of independent nations is intended. They shall have the same right of self-initiated progress which the Anglo-American race claims for itself.

14. The control of infectious disease is declared to be essential to the success of this alliance. For this purpose a tax may be laid on ocean commerce.

15. International commerce may also be organized and mass production encouraged so that a net profit may be created to pay the debts of nations incapable of meeting them.

16. Other coördinate nations may be admitted to this alliance if they accept these principles and permit public opinion to be molded by the same moral forces which create Anglo-American sentiment. 